\title{
A era pós-televisiva e a mediação de sentidos: uma perspectiva interdisciplinar
}

\author{
The post-television age and mediation of meaning: an \\ interdisciplinary perspective
}

\author{
Eduardo Portanova Barros ${ }^{1}$; Thayane Cazallas do Nascimento ${ }^{2}$
}

\section{Resumo}

$\overline{\mathrm{O} \text { presente trabalho se propõe a analisar a questão televisiva na pós-modernidade como mediadora de }}$ sentidos a partir de uma abordagem complexa e interdisciplinar. Este artigo é um contraponto ao livro "O homem na era da televisão", de Jean-Jacques Wunenburger. Procuramos situar a televisão para além da crítica, buscando um sentido da comunicação na vida social e nos domínios do campo simbólico. A referência crítico-judicativa se dilui no cotidiano pós-moderno, que se afasta das explicações totalizantes e binárias. O caminho da complexidade acaba sustentando com mais eficácia a relação entre o Eu-Outro, entre o Eu e o objeto e entre Eu e o mundo.

Palavras-chaves: Comunicação. Televisão. Imagem. Imaginário. Sociologia.

\begin{abstract}
This study aims to analyze the issue in television postmodernity as a mediator of meaning from a complex and interdisciplinary approach. This article is a counterpoint to the book "The man in the age of television," by Jean-Jacques Wunenburger. We try to place the television beyond criticism, seeking a sense of communication in social life and in the fields of symbolic field. The critical reference has been diluted in postmodernity, which avoid any fbinary and totalizing explanations. The path of complexity is more effectively to talk about the relationship of the Self and the Other or between the self and the object or, also, between I and the world.
\end{abstract}

Keywords: Communication. Television. Image. Imaginary. Sociology.

\footnotetext{
${ }^{1}$ Jornalista, professor, pós-doutor Université de Paris V (CEAQ/Sorbonne), pesquisador do Laboratório de Políticas Culturais no Brasil (LAPCAB/Unisinos), junto ao Programa de Pós-Graduação em Ciências Sociais da Unisinos, e do Grupo de Estudos sobre Comunicação e Imaginário da UFRGS. E-mail: eduardoportanova@hotmail.com.

${ }^{2}$ Mestre em Ciências Sociais pela Unisinos-RS. E-mail: thaycaz@hotmail.com.
} 


\section{Introdução}

Neste artigo, tomamos como proposta um contraponto à crítica de Jean-Jacques Wunenburger sobre a televisão. Para ele, "o efeito televisual adormece a consciência, diminui a vigília do pensamento". (WUNENBURGER, 2005, p. 29). Esse efeito anestésico de que fala Wunenburger tem um aporte crítico, sem dúvida, e, de certa forma, com justiça. Porém, nossa preocupação aqui é menos com a crítica do que um olhar desinteressado dos possíveis malefícios que o televisor possa causar para nossa "consciência refletida" (WUNENBURGER, 2005, p. 29). A televisão, na verdade, sobreviveu e sobrevive às críticas. Esta é a indagação-base deste artigo, ou seja: ainda se tem a televisão, mas, hoje, mesclada com outras "ferramentas" comunicacionais tão ou mais importantes que ela, como o computador. Este novo paradigma será denominado pós-televisivo. "Pós" porque a televisão já não é mais o que era antes do advento da internet, principalmente: agora elas se complementam. $\mathrm{O}$ aspecto principal do nosso foco é uma superação da crítica judicativa sobre a TV com uma troca de referencial para uma "razão aberta".

Toda crítica separa o objeto investigado. Nossa tentativa, aqui, é relevar a crítica e colocá-la em segundo plano. Para contextualizarmos nosso tema, comecemos citando McLuhan, o ensaísta canadense que cunhou os termos "aldeia global" e "o meio é a mensagem" e que ainda é referência nos estudos da Comunicação. Conforme McLuhan (1972, p. 15), "a passagem da tecnologia da roda para a do circuito elétrico representa uma das maiores mudanças de todo o tempo histórico". McLuhan, que Wunenburger destaca em seu livro também, chamou de Galáxia de Gutenberg "os modos pelos quais a formas de experiência e de visão e expressão mental foram modificadas, primeiro pelo alfabeto fonético e depois pela impressão tipográfica" (MCLUHAN, 1972, p. 18). Ainda de acordo com McLuhan (1972, p. 59), "a exteriorização dos nossos sentidos cria o que Teillard de Chardin chama a noosfera, ou seja, o cérebro tecnológico do mundo. O mundo converteu-se num computador, num cérebro eletrônico". Se os tipos móveis criaram o público e dessacralizaram o seu modo de ser, na opinião de Gutenberg, o que resta para ser visto? O próprio McLuhan tem uma postura crítica: "O tema deste livro [no caso "A galáxia de Gutemberg”] é: a inconsciência do efeito de qualquer força constitui um desastre, especialmente quando se trata de força que nós mesmos criamos" (MCLUHAN, 1972, p. 334).

A postura crítica de McLuhan, em nossa opinião, não é muito diferente da de Wunenburger (2005, p. 29), segundo o qual "o efeito televisual adormece a consciência, diminui a vigília do pensamento crítico, o que desencadeia uma espécie de receptividade aumentada aos estímulos externos". Quando McLuhan procura nos alertar para continuarmos conscientes, é análogo ao que Wunenburger pondera no sentido de que o efeito televisual diminui a vigília natural do pensamento crítico. Nestes dois autores, o viés crítico parece claro, mas existem outras maneiras, logicamente, de refletir sobre os efeitos da televisão (nocivos ou não). No ambiente familiar, o aparelho de televisão rivaliza, nesta época que chamaremos de pósmodernidade, com as interfaces do computador. Alguns programas (referimo-nos a seriados ou documentários), só disponíveis se baixados ou comprados no computador, acabam, através de uma conexão de cabos, sendo vistos no aparelho de tevê. Trata-se de uma simbiose total entre estes dois meios de comunicação e de informação.

Otimista em relação a essa etapa pós-moderna do avanço tecnológico, outro (além de McLuhan) teórico canadense da Comunicação, o filósofo Pierre Lévy (1993, p. 7), tem refletido sobre as "novas maneiras de pensar e de conviver estão sendo elaboradas no mundo das telecomunicações e da informática". O advento da tecnologia de ponta é transformador, segundo Lévy, por causa de uma metamorfose constante desses dispositivos e de aprendizagem da informática. "A técnica é um dos mais importantes temas filosóficos e políticos de 
nosso tempo", conforme Lévy (1993, p. 7). Uma inteligência coletiva está em formação, de acordo com ele. Consideramos que novas tecnologias intelectuais de que fala Lévy incluem a televisão tanto no sentido de recursos técnicos, hoje mais interativos, exemplificado com a conexão do computador na tela para ampliação da imagem, quanto de complexificação de conteúdo. Não entraremos no mérito se bons ou ruins, e sim que estes conteúdos simbolizam uma presença no mundo por osmose. Uma imagem puxa a outra e o telespectador acaba se envolvendo numa teia gigantesca de sentidos em frente a um televisor, cuja extensão é a internet.

Lévy (1993) considera a ideia de "inteligência coletiva" uma busca da hominização. O que está acontecendo na atualidade, segundo ele, é um processo de transformação social, através da virtualidade, Se, para ele, cada forma de vida inventa o seu mundo, até expandi-lo, a invenção tecnológica não tem limites. No entanto, caberia aos intelectuais, e é este o papel que Lévy atribui para si, estudar os sistemas simbólicos e aperfeiçoá-los. De acordo com Lévy (1993), um dos principais desafios dos intelectuais no século XXI é encontrar os meios mais eficazes de exploração de uma "inteligência coletiva", que ele chamou, considerando um novo problema, de "inteligência possível". Porém, um intelectual, hoje, não teria a mesma característica que antes, a de uma categoria especial de pensadores e de escritores, mas a de uma dimensão universal de toda a cultura. E qual seria o papel da televisão no mundo imaginado por Lévy? Seria a televisão, junto com outras ferramentas de comunicação, o meio de conscientização dessa proposta de "inteligência coletiva" de Lévy?

$\mathrm{Na}$ verdade, Wunenburger não se preocupou em projetar o futuro da televisão quando escreveu seu livro, cuja primeira edição, pela PUF (Presses Universitaires de France), foi em 2000. No Brasil, esta obra só saiu cinco anos depois. Hoje, após 13 anos, a tecnologia é outra e a televisão não se encontra mais isolada na sala, e sim expandida e de forma versátil. O homem, agora, vive a era da póstelevisão, o hibridismo com o computador, e é dessa simbiose que tratamos aqui, aceitando, sem dúvida, o fato de que a televisão, como diz Wunenburger, "pode", dentro de uma leitura crítica, pasteurizar o conteúdo; mas, por outro lado, é um componente lúdico e atraente de "comunhão emocional" (MAFFESOLI, 2012). Wunenburger (2005, p. 51) é bastante enfático: “[...] pode-se começar a sonhar com uma televisão que reinvente uma cultura real do espetáculo, que rompa com o que se assemelha muito apenas com os cínicos jogos oferecidos como repasto à multidão romana: panem et circenses". Se "aplicarmos" os estudos de Shannon e Weaver às características do meio televisivo, o olhar crítico de viés frankfurtiano se dilui. Vejamos o que eles dizem.

Para eles, a comunicação é, simplesmente, "um mecanismo que afeta o outro" (SHANNON; WEAVER, 1975, p. 4). Este mecanismo se apresenta de três formas ou níveis. No primeiro, os autores consideram o problema da exatidão ou técnico; no segundo, a questão é de caráter semântico (ou de precisão), e, no terceiro e último, o que se leva em conta é o problema da eficiência (no sentido comportamental). A comunicação se dá quando uma fonte transmite a mensagem através de um emissor por meio de um sinal que alcança um receptor. Essa é a síntese da ideia de comunicação em Shannon e Weaver. Foi com esse livro paradigmático - "A teoria matemática da comunicação" - que teria surgido a Teoria da Informação, uma vez que se procurou perceber como era o funcionamento de um sistema e, principalmente, como descrevêlo. Mudanças de um paradigma a outro, como o das tecnologias analógicas para as tecnologias digitais, também foram contempladas nesse estudo, publicado inicialmente em 1947. Este pioneirismo de Shannon e Weaver ainda é fonte para muitos estudos na área da Comunicação e serve de baliza para um embasamento epistemológico nesse campo. Até que ponto a televisão, como cultura de massa, cumpre com esse papel apontado por Shannon e Weaver? 
Para tentarmos refletir sobre este aspecto recorremos ao pensador francês Edgar Morin (1997), cuja obra abrange vários temas, do cinema ("O cinema ou o homem imaginário", dos anos 50) à complexidade ("Introdução ao pensamento complexo") (MORIN, 1991). Morin se dedicou, também, a escrever sobre a cultura. Seus dois livros sobre a cultura de massa estão longe de ser datados, mesmo que tenham sido escritos há bastante tempo, mais especificamente entre os anos 60 ("O espírito do tempo - Neurose". Vol. 1) e os anos 70 ("O espírito do tempo - Necrose". Vol. 2). "O eixo da cultura de massas deslocou-se. Seu campo ampliou-se, penetrando cada vez mais intimamente na vida cotidiana, no lar, no casal, na família, na casa, no automóvel, nas férias" (MORIN, 1997, p. 7). A televisão, nesse caso, era um - senão o principal - veículo de comunicação de massa a que se referia Morin. Nos anos 60 começava o "advento" da televisão. Em 1930, foi o da cultura de massa, nos Estados Unidos, o que Morin definiu como uma produção "segundo normas maciças de fabricação industrial destinando-se a uma massa social, um aglomerado gigantesco de indivíduos compreendidos aquém e além das estruturas internas da sociedade" (MORIN, 1997, p. 14). Segundo ele, é um conjunto de símbolos, mitos e imagens de projeções e identificações.

Vemos também, através da televisão, a ideia de uma comunicação interativa por meio de perguntas e respostas online, via msn ou via twitter, instantaneamente, sobretudo na modalidade do programa ao vivo, o que "gera" um novo modelo de fazer programas de TV, convidando o telespectador a construir este novo espaço social dentro da mídia. O telespectador, muitas vezes, faz o papel do pauteiro, aquela pessoa responsável pela escolha das notícias que deverão ser veiculadas em determinado veículo de comunicação. A figura do pauteiro não é privilégio da televisão. A televisão diária, assim, se tornou muito mais atrativa ao adotar este sistema nos noticiários de TV, nos programas de auditório e nos de entretenimento.
O "tire as suas dúvidas", na mesma velocidade que as recebe, incita o telespectador a participar "espontaneamente" de um novo arranjo midiático da televisão. O ibope não somente se baseia em números de espectadores, mas agora também na quantidade de twitteiros (seguidores), que estabelecem uma nova possibilidade de comparação entre índice de audiência e de popularidade virtual. A pós-modernidade, portanto, oferece, através dos meios de comunicação, esta abertura das novas relações sociais, abrangendo o que até então não se era pensado em termos de relação comunicativa, mas que, ao longo do tempo e devido aos avanços tecnológicos, possibilitou ao mundo que "falasse" e que se "expressasse" utilizando os aparatos oferecidos pela tecnologia.

A sociedade pós-moderna conta com a diferença e com o novo fluxo das experiências humanas, o mundo do espetáculo, do lúdico e da sedução. Em meio a estas transformações, a televisão é um veículo mais que apropriado para este cenário pós-moderno, pois garante o lazer com notícias, reportagens e curiosidades, em grande velocidade e num simples apertar de botão para a troca de canal. Assim, as certezas e verdades absolutas são descartadas. O que importa é a busca por "verdades instantâneas", que garante um interesse muito maior e, sem dúvida alguma, para os temas da moda, como beleza, culinária e as diferentes "estéticas". Através da busca das nossas "verdades", existe a permissividade de contemplação de si mesmo dentro do mundo fantástico, em que as nossas escolhas podem ser feitas pelo gosto que nos convém, com valores ou sem valores de moral. Este é o prazer da escolha. E é neste cenário da permissividade que a informação ganha conteúdos muito mais acessíveis ao entendimento das imagens do que o conteúdo dos textos críticos. A televisão como "veículo de sedução" - se assim podemos dizer - satisfaz os sentidos visuais, atrativos aos olhos, irresistíveis através do jogo da moda, da violência, do consumo, da beleza e do prazer. Trata-se de um universo estético e sedutor. Por que não fazer parte dele? 
Já na Indústria Cultural, um conceito criado por Adorno e Horkheimer, ambos integrados à chamada Escola de Frankfurt, de viés marxista, os meios de comunicação de massa são analisados sob o ponto de vista da Teoria Crítica. Comparavam a produção industrial da cultura com a organização, por exemplo, de uma fábrica de automóveis. Tudo era produzido em série e, por causa disso, a arte passava a se integrar ao sistema. A arte perdia sua aura, seu valor, sua importância. Esse era o resultado, segundo eles, da padronização dos bens culturais. São muitos os pensadores que ainda observam a relação entre arte e cultura dessa forma. O cineasta Jean-Luc Godard, por exemplo, afirmou em um de seus filmes, "JLG por JLG”, que a arte é exceção; cultura, a regra. O ensaísta francês Alain Finkielkraut (1988), por exemplo, escreveu um livro para criticar a perda do sentido aurático de uma obra de arte e intitulou-o "A derrota do pensamento". É uma alusão clara à barbárie cultural que é quando não se distingue mais a qualidade de gênio de um Bach e o "pop" de Lady "Bad Romance" Gaga.

A mesma sociedade que idolatra a televisão promove, na opinião de Alain Finkielkraut, a derrota do pensamento. Para ele, a barbárie se apoderou da cultura por meio da industrialização do lazer, e "as obras do espírito teriam sido reduzidas a quinquilharias" (FINKIELKRAUT, 1988, p. 158). Por "obras de espírito" leiam-se, também, filmes autorais. Pessimista, Finkielkraut (1988) divide a cultura em superior, média (midcult) e inferior $(\text { masscult })^{3}$. Trata-se, não há dúvida, de uma leitura elitista de cultura, que lamenta a suposta extinção da fronteira entre cultura e divertimento. Se a cultura de massa é irreversível, não seria melhor perguntar: o que fazer com ela? E, neste caso, há uma forte dose de subjetividade. O que acontece quando um operário se interessa por um filme de Godard e o próprio Godard se interessa por um filme de Spielberg? A divisão entre culturas não é tranquila. O autor de "A derrota do pensamento" vive no Iluminismo, pois acredita em valores universais. Logo, critica o multiculturalismo. Se Finkielkraut (1988) acredita na tese de uma cultura superior, média e inferior, isso é um indicativo de uma Teoria Crítica que vai distinguir o que é bom e o que é ruim em termos artísticos.

A obra de arte seria só para iniciados, porque, apenas eles, seriam capazes de entender a mensagem de seu autor. É coisa de gênio, como nos referimos antes, e não de consumo ligeiro para seres humanos comuns, medíocres e massificados pela televisão. Para Finkielkraut, agora não é mais possível sermos sujeitos autônomos, esclarecidos, cultos, conscientes, criteriosos, inteligentes, já que somos devorados pelo leviatã pós-moderno: a televisão. Trata-se, como ele diz, de satisfazermos desejos imediatos e de divertimento pelo menor custo. Finkielkraut (1988) cita, no início de seu livro, a passagem de um filme de Godard, Viver a vida (1962), em que um filósofo, interpretado por Bruce Parain, dialoga com Naná (grafia em português), a protagonista do filme, interpretada por Anna Karina. Segundo Finkielkraut, o filósofo opõe a vida cotidiana à vida com o pensamento (superior). $\mathrm{Na}$ estética pós-moderna, o conteúdo dá lugar ao continente. O conteúdo é fechado, hermético. O continente é amplo, herético: assim como a filosofia de Nietzsche (2002, p. 184): “[...] o mundo e a existência não podem ter justificação alguma, a não ser como fenômeno estético". A vida, na pósmodernidade, é a própria obra de arte no cotidiano.

\footnotetext{
${ }^{3}$ Conforme Teixeira Coelho (1983, p. 14), estas divisões foram estabelecidas por Dwight MacDonald, que falou de manifestações culturais em termos de superior, média e de massa ou inferior. "A cultura média, do meio, é designada também pela expressão midcult, que remete ao universo dos valores pequenos burgueses; e a cultura de massa é por ele chamada, pejorativamente, de masscult".
} 
A sociedade, agora, não é uma superestrutura. É uma fragmentação do fugaz em vista dos novos valores e comportamentos culturais. A televisão como meio deste campo das relações comunicativas exprime muito mais do que "facilidades" de interação. A tevê também é representada por suas particularidades e marcas próprias que estabelecem um sistema específico para além da ideologia marxista subjacente à Teoria Crítica. Armand e Michèle Mattelart (1999, p. 9), por exemplo, reconhecem que "a noção de comunicação recobre uma multiplicidade de sentidos e que a proliferação das tecnologias e a profissionalização das práticas acrescentaram novas vozes a essa polifonia”. O mesmo pode se dizer da televisão como um veículo que oferece diversidade de programação, hoje com recursos mais interativos, como a escolha de filmes por assinatura. Neste sentindo, buscamos interpretar as características pós-televisivas não só pelo lado da informação ou alienação, mas também em comunicar (colocar em comum), permitindo muito mais o compartilhar do cotidiano pelas emoções do que pelos informativos realísticos.

Maximizam-se as relações interativas conforme uma "partilha" das emoções, em contraponto ao senso crítico da realidade política e da desigualdade social. Maffesoli, conforme Juremir Machado da Silva, percebe a comunicação como uma forma sensível da vida social contemporânea: "Tenta compreender, fora dos imperativos morais, como ela serve de 'cimento social numa época de crise das velhas certezas e de desabamento das antigas utopias políticas" (SILVA, 2004, p. 44). Wunenburger, em "O homem na era da televisão", se pergunta: o que será da cultura com o triunfo televisivo? Cultura, obviamente, no sentido frankfurtiano do termo. Quando se vê um filme de Bergman na tevê, por exemplo, estamos diante de uma obra incomum e autoral ou de mais um filme de entretenimento rasteiro? Esse questionamento Wunenburger também apresenta. Não devemos esquecer que o próprio Bergman e também Godard produziram obras especialmente para a televisão. Portanto, na nossa opinião, não é pelo fato de um filme autoral - podemos dizer assim - passe na televisão que ele será menos autoral.

A tevê serve de inspiração para o "realismo" com que Godard (1989, p. 247) costura seus filmes, como ele próprio confessa: “[...] desenvolvi, nos últimos tempos, essa ideia de que, para mim, o que tento fazer é misturar o documentário e a ficção, é antes misturar um pouco a televisão e o cinema". Godard disse que aproveita a forma do documentário ou o vivido. O filme Cenas de casamento, por exemplo, estreou em abril de 1973 na televisão, dividido em seis episódios. Existe uma versão (cinematográfica) destinada para outros países, entre eles os Estados Unidos, que dura 155 minutos. Para Wunenburger (2005, p. 106), a televisão se beneficiou do cinema, "uma arte maior do espetáculo do século XX do qual ela parasitou as obras difundindo-as e repetindo-as frequentemente, por sua própria conta, mesmo que tenha se tornado, por sua vez, após muito tempo, parceira na realização de produções cinematográficas". Quanto ao cinema, foi do romance que extraiu suas narrativas, ao visualizar e sonorizar histórias que antes só existiam na imaginação dos leitores, agora encantados com os 24 fotogramas (hoje digitalizados) por segundo. O cinema, para Wunenburger, acabaria ampliando um público que só conhecia o modo livresco da ficção. Esse poder do cinema é herdado pela televisão, de acordo com o autor. Só que, segundo ele, essa herança acaba transformada, prostituída e comprimida pelo novo meio audiovisual. "Muitos filmes perdem todo o seu valor estético quando apresentados na tevê, mesmo agora que a indústria parece ter se lançado na produção de telas cada vez maiores" (WUNENBURGER, 2005, p. 107).

Em resumo, a televisão suscita uma bulimia de filmes que intensifica o ciclo ingestão-digestão de imagens, mas priva o espectador, ao mesmo tempo, dos metabolismos simbólicos que lhe permitiriam transformá-las, pela fantasia, pelo trabalho de anamnese e pela apropriação simbólica, em materiais para seu imaginário (WUNENBURGER, 2005, p. 108). 
Já o imaginário, para Maffesoli, é o de uma sensibilidade pós-moderna. Quando se trata de analisar a questão da comunicação, é a de uma atmosfera holística revestida de significados culturais subjetivos nas relações humanas. Colocase em outro âmbito que o da rígida e cartesiana modernidade, objetivada na construção dos valores morais. O "sair-se de si" para "encontro do outro" dimensiona a interação desta relação predominante nos tempos atuais que se utiliza dos aparatos da tecnologia e dá novos sentidos a uma realidade das relações sociais atuais através das redes de relacionamento do Facebook, dos blogs, do Orkut, do Twitter, do Msn etc., para sedimentar emoções e partilhar o cotidiano. A pós-modernidade também é ilusão, é volátil, é simulação de fatos. A mídia utiliza muito bem estes mecanismos para "fazer mídia", sobretudo aplicando aos meios de informação da televisão o uso das imagens como meios subjetivos em vez de conteúdos cognoscíveis. Sobre a televisão propomos neste trabalho uma análise sociológica, por considerar a sua importância no espaço social. A "era das incertezas" na sociedade pós-moderna reordena os meios de liberdade.

Aprofundando um pouco mais a questão do simulacro, mencionado no parágrafo anterior, Baudrillard identifica que a distância é abolida e que a interatividade nos ameaça por toda parte: "Essa confusão dos termos e essa colisão dos pólos fazem com que em mais nenhum lugar haja a possibilidade do juízo do valor: nem em arte, nem em moral, nem em política”. (BAUDRILLARD, 1997, p. 146). A televisão não seria a reprodução exata deste momento em que a sociedade já não julga e não se envolve com os temas relacionados, em que tudo morre na interação vazia? E a televisão não estaria refletindo esta perda de valores? Estes questionamentos de Baudrillard se assemelham aos de Wunenburger. Baudrillard (1991, p. 8) afirma que hoje se observa um real "sem origem nem realidade, o hiper-real”. A televisão, acreditamos, é, em grande parte, responsável pela visão crítica de pensadores como Baudrillard. Porém, como afirmamos anteriormente, outros elementos, que não só sob uma perspectiva crítica, redimem a televisão. Uma manifestação política, por exemplo, vai além do seu conteúdo político. É uma comunhão emocional, diria Maffesoli (2012).

Utilizaremos o que Baudrillard (1997, p. 13) aponta como fases sucessivas de imagem. Primeira fase: é o reflexo de uma realidade profunda. Segunda fase: ela mascara e deforma a realidade profunda. Terceira fase: ela mascara a ausência de uma realidade profunda. Quarta fase: ela não tem relação com qualquer realidade, ela é o seu próprio simulacro. Com base nestas quatro fases da imagem, absorvemos o que dela mais nos apoderamos entre a relação com a realidade, é que esta faz qualquer realidade, e sobre o poder que esta exerce sobre os valores e signos sociais. Presenciamos estes "jogos" de poder sobre a imagem em um entrelaçar perfeito entre a sociedade pós-moderna e a construção da televisão. O domínio da televisão sobre os signos de poder, de interesses políticos e econômicos, se constitui em um campo que oferece muito mais aos sentidos do que a reflexão. Neste contexto, a imagem não só fala como se basta à análise semiótica. $\mathrm{O}$ viés de Baudrillard é tão crítico quanto o de Wunenburger.

Vattimo (1996), por sua vez, nos proporciona uma compreensão sociológica sobre a teoria do fim da modernidade, possibilitando em uma de suas passagens a crítica aos meios de comunicação como uma "des-historiadora", em que existe uma dissolução da história através dos instrumentos de informação. Para (VATTIMO, 1996, p. xiv) "dissolução, decerto, significa, antes de tudo, ruptura da unidade, e não fim puro e simples da história. Percebeu-se que a história dos eventospolíticos, militares, dos grandes movimentos de ideias- é apenas uma história entre outras".

Como observa Nicola Tranfaglia, isso depende do fato de que o mundo da mídia disseminada por todo o planeta também é o mundo em que se multiplicaram os "centros" de história - as potências capazes de recolher e transmitir as informações com base numa 
visão unitária, que também é sempre o resultado de opções políticas (VATTIMO, 1996, p. xvi).

E ainda completa sobre a história contemporânea, que é o que nos interessa focalizar sobre os meios de comunicação,

A história contemporânea, desse ponto de vista, não é apenas a que diz respeito aos anos cronologicamente mais próximos de nós; ela é, em termos mais rigorosos, a história da época em que tudo, mediante o uso dos novos meios de comunicação, principalmente a televisão, tende a nivelar-se no plano da contemporaneidade e da simultaneidade, produzindo também, assim, uma dês-historicização da experiência (VATTIMO, 1996, p. xvi).

Esta visão sobre a história nos dá os instrumentos necessários para que haja uma possibilidade de construção teórica sobre a mídia na pós-modernidade, a fim de que nos possibilite interpretar, pelo viés de uma leitura compreensiva, o sentido que é dado à mídia neste novo cenário, nos perguntando em que momento acontecem as alterações sobre esta ferramenta de comunicação e em que implicam estas mudanças na sociedade pós-moderna. Segundo Paiva, Vattimo mostra-se otimista quanto aos meios de comunicação:

O pensador comemora este novo momento porque "diante do risco de uma cultura de imersão, de uma vila global comunitária, populista, tendencialmente autoritária e acrítica, onde o sujeito, tal como nós temos conhecido até hoje, tende a desaparecer, a única via de saúde parece ser uma recuperação da relação texto-intérprete, ou ao menos, certos traços desta relação"7. O fato é que ele reafirma sua proposta contida em $A$ sociedade transparente, recusando a visão pessimista da Escola de Frankfurt para com a sociedade midiatizada. Sua argumentação retoma a concepção heideggeriana do desaparecimento do sujeito, para interrogar se seria possível uma saída para a dissolução do sujeito, e encontra as novas condições da comunicação de massa como oportunidade positiva de uma nova relação do homem com o Ser que não seria mais metafísica, portanto não mais alienada. Ou seja, uma nova oportunidade de emancipação (PAIVA, 2006, p. 202).

Vattimo observa a dificuldade, mesmo considerando-a formalista, em identificar alguma mudança autêntica na forma de pensar ocidental.
Porém, se o pós-moderno for uma dissolução, e não uma novidade ou uma etapa posterior da modernidade, as coisas mudam. Entra em cena a noção de catastrofismo, na qual o progresso já não assegura um futuro promissor e redentor, mas sim a rotina, por causa de uma disposição do ser humano em transformar a natureza através do aparato tecnológico e garantir resultados: um novo sempre igual. O mundo técnico seria não-histórico, conforme a leitura que Vattimo faz de Heidegger, rompendo-se a ideia de unidade da pretensa história universal no curso dos acontecimentos. Vattimo lembra que, a partir de Gutenberg, tornou-se possível, para o homem moderno, viver sua história de forma linear e progressiva, mas que, na Idade da Televisão (ou Idade da Internet ou pós-televisiva, como sustentamos aqui), se tornou humanamente impossível devido à globalização dos centros de história. Tudo é simultâneo. Estaríamos vivendo, então, uma crise dos valores humanos? Por que insistir na valorização da arte como produto humano e não como resultado técnico?

Marshall Mcluhan (2005), também crítico da comunicação, trabalha, reiteramos aqui, a questão da televisão como objeto de controle do homem. Este autor, porém, vai mais além da crítica à comunicação, falando não só da televisão, mas do rádio e dos jornais impressos. Quanto a isso, McLuhan é cuidadoso, principalmente sobre a questão do sentido da vida em meio a este processo, pois sofreríamos "manipulação particular daqueles que procuram lucrar arrendando nossos olhos, ouvidos e nervos" (McLUHAN, 2005, p. 88). Para McLuhan, assim como para Wunenburger, a televisão impõe um estilo. "Ela tomou o lugar das igrejas ou das universidades para definir aquilo em que se deve acreditar, o que se deve saber, admirar, na orientação das decisões ou reformas" (WUNENBURGER, 2005, p. 103).

A sociedade pós-moderna como sociedade da comunicação nos possibilita duas formas de análise dos meios de comunicação: em um primeiro momento, podemos dizer que as relações sociais se 
tornam enfraquecidas pela dependência que existe em se comunicar à distância. Em um segundo momento, temos a análise sob o aspecto dos aparatos modernos, nos quais as pessoas não se tornam distantes, no sentido de se "estar com o outro" em um mesmo espaço, porém isso não significa que estejam menos "presentes" as "distâncias" são superadas devido aos avanços tecnológicos.

Guattari, por exemplo, fala-nos desta era "pósmídia", "caracterizada por uma reapropriação e uma re-singularização da utilização da mídia (acesso aos bancos de dados, videotecas, interatividade entre os protagonistas etc.)". (1992, p. 16) Por sua interatividade, esta perspectiva tende a alterar substancialmente a abordagem midiática tradicional ou, pelo menos, tende a oferecer outros contornos (LUCAS, 1998, p. 29).

O sistema midiático da televisão seria um objeto importante de análises e críticas. Sabemos que este sistema de interação proporcionado pela televisão não basta para que possamos criticar o seu conteúdo e suas formas de controle em um dissimularsimulando. O contexto da crítica se direciona a pensar sobre o exercício da "representação". Qual é a realidade que vemos? Esta é real? Qual é o papel que a televisão possa a vir a desempenhar?

Os conteúdos da comunicação de massa, de um modo geral, perdem-se em meio à tentativa de sedução no $\mathrm{de} \neg$ correr do aprimoramento inigualável de sua técnica e na superficialidade de suas abordagens. Já não podem responder - até em função da amplitude de seu al $\neg$ cance - a um universo que se fragmenta em tribos com particularidades muito diferentes. A abordagem de massa não consegue assimilar toda essa pluralidade sem perder em profundidade caracterís $\neg$ tica que só um tratamento mais dirigido e interativo poderá oferecer (LUCAS, 1998, p. 28).

Os espaços da sociedade da comunicação também deixam em aberto futuras críticas nas quais exclusão e alienação possibilitam um espaço significativo para se pensar a televisão como meio de comunicação de massa. O que estaríamos assistindo? Os interesses políticos e econômicos dão sentido às críticas pertinentes sobre este meio de comunicação? Não obstante, a comunicação não só possibilita o encurtamento dos espaços, através dos avanços tecnológicos, mas também a interpretação das culturas numa sociedade pós-moderna, na qual as relações sociais são pensadas e vistas por outro ângulo.

Em consequência disto, assistimos hoje ao aparecimento de formas de comunicação que estimulam o feedback e que permitem um conhecimento maior sobre o receptor da mensagem. Os bancos de dados são um exemplo claro desta nova abordagem. Vemos hoje um número crescente de organizações procurando entender melhor os hábitos de consumo e o estilo de vida de seus clientes, para poderem estabelecer uma interação, o que a mídia de massa não permite alcançar (LUCAS, 1998, p. 28).

Ideologia, que é forma do pensamento crítico, e aqui concordamos com Maffesoli, carrega uma aura demasiadamente política, que, na pós-modernidade, tem sido questionada - e, para muitos, superada como o valor universal de uma sociedade. Esta, hoje em dia, é repensada de muitas outras formas que não só as de natureza contratual, como prevalece na crença numa ideologia.

\section{Considerações finais}

Procuramos mostrar, primeiro, que $o$ isolamento que se faz de um objeto pelo pensamento crítico prejudica uma visão complexa desse mesmo objeto. O complexo, aqui, é tomado de empréstimo de Morin, que nos diz que a complexidade é palavraproblema e não palavra-solução. É o patriarca da teoria segundo a qual somos homo, ao mesmo tempo, sapiens, demens, ludens, mitologicus e poeticus. Estas dimensões do humano estão interligadas, e é precisamente esse aspecto que torna o pensamento complexo de Morin tão difícil de ser assimilado por quem pensa sob a lente da modernidade, a que vê tudo de forma fragmentada, a característica principal de um pensamento crítico binário. Se nos dedicarmos a refletir demoradamente sobre a complexidade de Morin, veremos que ela não é tão simples como se imagina. Por exemplo: como entender que o universo é imperfeito, mas que essa 
imperfeição de que é feito também é a condição de sua existência? Com isso, Morin desmonta o saber prometéico de avançar para corrigir, o que não deixa de ser a mesma crítica que faz Maffesoli à lógica do "dever-ser". Em "Ciência com consciência", Morin (2001) postula uma "razão aberta".

Se pensarmos a televisão dentro do pressuposto de Morin de uma razão aberta e não de uma razão crítica, veremos aspectos híbridos que não seriam observáveis anteriormente por uma visão de mundo afirmando a concordância perfeita entre o racional (coerência) e a realidade do universo. Detenhamonos um pouco mais no trabalho de Morin. Ao escrever, no final dos anos 50, sobre cinema, Morin destacou a relação entre o cinema e o (homem) imaginário. Ele próprio fez um filme: Cronique d'un été, de 1962, em co-autoria com o etnólogo Jean Rouch, no auge da Nouvelle Vague francesa. Morin despertou outros teóricos para o fato de que existe uma aura (o que nos remete ao artigo de Walter Benjamin sobre "A obra de arte na época de sua reprodutibilidade técnica") antes sentida do que conscientizada, em toda ação humana.

O cinema, como a cultura de massas, vive (sobre) o paradoxo de que a produção (industrial, capitalística, estatal) tem necessidade de, simultaneamente, excluir a criação (que é desvio, marginalidade, caos, desestandardização), mas também de a incluir (porque é invenção, inovação, originalidade, e porque toda obra tem necessidade de um mínimo de singularidade); e tudo se joga, humana, aleatória, estatística e culturalmente, no jogo criação/produção (MORIN, 1997, p. 18).

Este aspecto fluido, o da sensibilidade, que não pode ser descrito pela linguagem, mas nem por isso negligenciável, pode ser o imaginário. Vivese, no caso do cinema, uma projeção-identificação com aquilo que é visto na tela. Para Morin, isso é tão significativo que resolveu escrever mais tarde, em 1972, outro livro sobre cinema, desta vez sublinhando o aspecto mitológico das estrelas ("As estrelas - mito e sedução no cinema"). A tríade humano-biológico-cultural é inseparável no ser humano, diz Morin (pois ela carregaria nossos afetos, nossas pulsões e nossa racionalidade). Tratase de um todo cujas partes até poderiam ser distintas, mas nunca isoladas entre si, como Wunenburger faz, neste livro, em relação à televisão. Morin fez questão de organizar seu pensamento metodologicamente. Os seis livros dessa fase, que se estendeu por vários anos e que foi concluída depois da virada do milênio com a publicação de "O método 6 - ética" (MORIN, 2005), apresentam como que uma unidade múltipla (unitas multiplex) da sua tese. A ideia central do último trabalho na linha das metodologias é a de que a ética não pode escapar dos problemas da complexidade, e o conhecimento complexo se tornou vital na sociedade contemporânea.

É preciso praticar a complexidade, e essa prática começa no indivíduo (o que, para Maffesoli, poderia ser melhor designado pela palavra pessoa, por causa da relação, etimologicamente falando, de persona-máscara-pessoa e, consequentemente, com o papel que desempenhamos e que varia conforme as circunstâncias). Dá para aceitar, por exemplo, o sentimentalismo familiar dos chefões da máfia? Como compreender a intimidade entre Truman Capote e os assassinos de uma família no Kansas, entre o final dos anos 50 e início dos 60 ?

Para Morin, compreender um assassino, como no exemplo anterior, não significa compactuar com ele. É o que ele chama de "moralina", isto é, o julgamento com base em critérios exteriores ou superficiais de moralidade. Morin defende uma ética da compreensão, e, nesse ponto, o imaginário tem um papel de destaque, pois, nele, o julgamento não tem qualquer valor. A exemplo de Maffesoli e Durand, que criticam o saber endurecido, Morin (2005, p. 111-112) afirma: "O mundo dos intelectuais, que deveria ser o mais compreensivo, é o mais gangrenado pela hipertrofia do ego, pela necessidade de reconhecimento e de glória".. Portanto, poderíamos nos arriscar a repetir a fórmula de Morin para falar de imaginário: como aprender a compreender ou como compreender a compreensão? E é em torno do imaginário que gira o pensamento de Morin. Para ele, não se pode isolar 
a pessoa do seu universo. Tudo o que vivemos faz parte de um holograma, por vezes feliz, por vezes triste; por vezes dramático, por vezes trágico. Não se pode, de acordo com ele, pensar a estrutura civilizacional em termos binários, caso contrário estaríamos excluindo o terceiro elemento, que é, para Morin, a relação que associa o par binário.

Por isso, para Morin, a pessoa se enquadraria em uma "lógica de antagonismos", a da ordem e a da desordem. O trabalho de Morin é referência não só na área da comunicação. Devido aos estudos da complexidade, Morin (2001) aborda outros campos do saber, sobretudo na educação, um tema que tem merecido grande esforço intelectual do autor de "Ciência com consciência". Morin, enfim, postula uma reforma do pensamento por meio de uma ética de si para si.

Também afirmamos que a televisão não é um veículo alienante, pois, com base na Teoria da Comunicação, a função precípua desse termo é ligar. A televisão coloca em comum uma partilha de afetos, dificilmente observáveis criticamente. Na sociedade do espetáculo de Guy Debord (1997), deixamos de ser protagonistas e nos tornamos atores coadjuvantes. Para Debord (1997), a saída é a crítica, nem que seja para, por meio de uma tela escura, afirmar: o cinema está morto. Oscilando entre o marxismo e o anarquismo, Debord opina, enfim, que o espetáculo justifica o injustificável, e que seria necessário um retorno à autenticidade com a ajuda da crítica (tese 204). Termos como autenticidade e crítica, na pós-modernidade, sofreram, porém, uma transformação (para não sepultá-los de vez). Debord (1997) lamenta a progressão da sociedade rumo ao espetáculo, cujo valor de autenticidade teria perdido o sentido. Para ele, pensar que o espetáculo também apresenta alguma espécie de autenticidade, nem que seja a sua mesma, é impensável. Todo pensamento crítico julga conhecer (ou alcançar, melhor dizendo) o que se esconderia por trás de duas coisas, a superfície e a aparência. Só não espera que uma e outra sejam nada mais do que aquilo que elas próprias $s \tilde{a} o$, sem nada a esconder.
As duas propostas de raciocínio sobre a televisão abordadas acima - a de que a crítica isola e a de que a televisão não é alienante - nos remete à inclusão de um terceiro aspecto: o de que, em sendo da forma como mostramos, a modernidade está em ruínas. Se a modernidade está debilitada, o que vem no lugar ou o que vai se construindo, tomando como referência a própria modernidade? Justamente a pós-modernidade, na falta de um termo melhor. Maffesoli é o teórico que se impõe como referência quando se fala de uma fenomenologia do imaginário baseada no cotidiano. O autor de "O tempo das tribos" (MAFFESOLI, 2000) insiste em dar importância para o imaterial, a aura e o não-racional nas relações sociais. Outra questão interessante na obra dele é que o Ocidente não teria se rendido apenas ao trabalho árduo para ter, como recompensa, um futuro melhor. Maffesoli (2001) acredita, porém, em um estar-junto societal. Ou seja, a vida que se cristaliza no instante ("O instante eterno"): um instante mágico, afirmativo. Este instante é a marca da pós-modernidade. Na modernidade, porém, o mito prometeico (trabalhar para colher os fruto e acreditar piamente no progresso) assumia um papel de destaque, o de um sujeito institucionalizado e racional.

A modernidade era fundada no individualismo: se eu trabalhar serei recompensado. Na direção oposta, o mito dionisíaco da pós-modernidade valoriza a exacerbação dos afetos, o orgiástico e o tribalismo. Grupos se juntam com objetivos comuns. A tribo é fechada, mas solidária. Na pós-modernidade, não se procura a superação dialética de elementos opostos, pois tudo é complexo. Assim, a televisão não pode ser mais isolada de seu contexto imaginal e, por isso, denominamos pós-televisivo este estágio em que ela se encontra, Um estágio cuja referência maior é o relativismo. Pode ser tanto no sentido de relacionar, o pôr em relação, quanto o de relativizar a crítica. O próprio Wunenburger (2005, p. 139) aponta nessa direção ao final do livro: "Que lugar conceder ao sensível, à imagem, para desenvolver nosso pensamento e nossa razão?". 


\section{Referências}

BAUDRILLARD, J. Tela total mito ironias da era virtual e da imagem. Porto Alegre: Sulina, 1997.

. Simulacros e simulação. Lisboa: Relógio d'Água, 1991.

COELHO, T. O que é indústria cultural. São Paulo: Brasiliense, 1983.

DEBORD, G. A sociedade do espetáculo. Rio de Janeiro: Contraponto, 1997.

FINKIELKRAUT, A. A derrota do pensamento. Rio de Janeiro: Paz e Terra, 1988.

GADEA, C. A.; BARROS, E. P. A "questão pós" nas Ciências Sociais: crítica, estética, política e cultura. Curitiba: Appris, 2013.

GODARD, J. L. Introdução a uma verdadeira história do cinema. São Paulo: Martins Fontes, 1989.

LÉVY, P. As tecnologias da inteligência: o futuro do pensamento na era da informática. Rio de Janeiro: Ed. 34, 1993.

LUCAS, L. O consumo como ethos contemporâneo: dos paradoxos à mecânica de sedução. Revista Logos: Comunicação e Universidade, Rio de Janeiro, ano 5, n. 9, p. 26-31, 1998.

MAFFESOLI, M. Homo eroticus: des communions émotionnelles. Paris: Ed. CNRS, 2012.

- O tempo das tribos: o declínio do individualismo nas sociedades de massa. Rio de Janeiro: Forense Universitária, 2000.

- Elogio da razão sensível. Petrópolis: Vozes, 1998.

. O instante eterno. Lisboa: Instituto Piaget, 2001.

A parte do diabo: resumo da subversão pós-moderna. Rio de Janeiro: Record, 2004a.

Notas sobre a pós-modernidade: o lugar faz o elo. Rio de Janeiro: Atlântica, 2004b.
MATTELART, A.; MATTELART, M. História das teorias da comunicação. São Paulo: Loyola, 1999.

McLUHAN, M. A galáxia de Gutenberg: a formação do homem tipográfico. São Paulo: Nacional, 1972. Os meios de comunicação como extensões do homem. São Paulo: Cultrix, 2005.

MORIN, E. Cultura de massas no século $X X$ : neurose. Rio de Janeiro: Forense Universitária, 1997.

. O método 6: ética. Porto Alegre: Sulina, 2005

Introdução ao pensamento complexo. Lisboa: Instituto Piaget, 1991.

Ciência com consciência. Rio de Janeiro: Bertrand Brasil, 2001.

O cinema ou o homem imaginário. Lisboa:

Relógio d'Água, 1997.

NIETZSCHE, Friedrich. A origem da tragédia. Lisboa: Guimarães, 2002.

PAIVA, R. A potência emancipatória da comunicação. Alceu, Rio de Janeiro, v. 7, n. 13, p. 199-280, jul./dez. 2006.

SHANNON, C.; WEAVER, W. Teoria matemática da comunicação. São Paulo: Difel, 1975.

SILVA, J. M. Michel Maffesoli, teórico da comunicação. Revista: Famecos, Porto Alegre, n. 25, 2004.

VATTIMO, G. O fim da modernidade: niilismo e hermenêutica na cultura pós-moderna. São Paulo: Martins Fontes, 1996.

WUNENBURGER, J. J. O homem na era da televisão. São Paulo: Loyola, 2005.
Recebido em: 17 nov. 2013. Acesso em: 20 dez. 2013. 